would preserve for us the great variety of knowledge which his sensitive, inquiring mind has gathered. Nevertheless, here is a book written graciously, one which in the opinion of the reviewer stands out as Seton Gordon's best.

The only plan the book can be said to follow is based on the title of "A Highland Year", the chapters being the months, beginning at October, which is a good choice. Within his months, Seton Gordon allows himself complete freedom of anecdote and description, jotting down in leisurely fashion an immense range of facts of natural history. Observers studying bird behaviour will find several points of interest: for example, a case of a black-throated diver moving her eggs from one islet to another in a hill loch during a heavy spate. This bird continued to sit on the eggs in their new place. A wagtail's nest in a quarry on the new Glencoe road was moved several yards by the navvies to a new site on the quarry floor, where they built a cairn round the nest to give it shade and protection. The birds continued to sit in the new place and reared their young, blasting, lorry-loading and hubbub notwithstanding. These occurrences are in such sharp distinction to that narrowly limited pattern which Howard with corn buntings and Kirkman with black-headed gulls have shown to be common in the perception of the nest site.

The influence of man on wild animal life in Scotland is described in many notes. Ptarmigan, for example, are extinct in the Forest of Harris, their last haunt in the Outer Isles. Rabbits increased to such an extent on the Slopes of Clisham, the highest hill $(2,665 \mathrm{ft}$.), that someone put down ferrets. It would not have needed much actuarial knowledge to have contrasted the reproductive potentials and expectations of survival of these two species. Ptarmigan have gone; the rabbits remain. Less than a century ago, the pine marten was common in these treeless hills, but its influence on the ptarmigan was apparently much less harmful than that of the ferret.

Seton Gordon often speaks of the lobster fishery of the West Highland and Hebridean coasts : it has been prosecuted with intensity during the War, but as yet we know little or nothing of the cropping potential of this valuable wild-life resource. It is unfortunate that public opinion has not yet enforced what provident common sense dictates in the handling of these shellfish. Lobsters are still sent to Billingsgate alive with an estimated consequent loss of 25 per cent. Many lobster fishers still 'cut' their catch, that is, prevent these shellfish fighting in the crowded conditions of the box by severing the tendon of the main elaws at the joint. This suffering could be eliminated by installation of 'quick-freeze' plants in the catching areas and transport costs would be reduced.

Seton Gordon the naturalist tends to overshadow the judge and talented player of the Highland bagpipe. He is an authority on ceol mor, the 'great music' of Gaeldom. The piobaireachd is a severely disciplined classical form comparable with the fugue, but a bigger thing altogether; yet the author of this book considers, with other pipers, that piobaireachd is dying. Is this because the bagpipe remains a solo instrument for its classical music, and times and places are few in modern life when this form can be appreciated? Perhaps we may yet see the piobaireachd orchestrated and brought to a wider field of music lovers.

\section{FOOD SCIENCE}

\author{
The Chemistry and Technology of Food and \\ Food Products
}

Prepared by a Group of Specialists under the Editorship of Dr. Morris B. Jacobs. Vol. 2. Pp. $x x+890$. (New York: Interscience Publishers, Inc., 1944.) 10.50 dollars.

L.JALF of this volume is concerned with unit -1 operations and processes (describing generally the methods and equipment involved in the preparation of foods), food supervision by government agencies, sanitary and quality control, food machines, plant sanitation, control of insects and rodents, dehydration, food preservation by temperature control and by micro-organisms, canning, chemical preservatives and packaging. The other half deals with production and covers the milling of cereals, bread and bakery products, sugars, chocolate, fruit juices, milk and milk products, meats, oils and fats, beverages and industrial waters.

The book suffers from the weakness of being too comprehensive, and as a result many important aspects are dealt with inadequately. It is doubtful if the section on food supervision will interest the average food technologist, while the engineer interested in machines for food processing would probably gain more from a study of the elaborate catalogues produced by manufacturers. By contrast, the section on plant sanitation is so loaded with detail that the principles and remedies tend to be lost. The sections on insect and rodent control make interesting reading, but it is obvious that American work is behind our own on, say, the question of insecticidal dusts. Again, no mention is made of critical moisture con. tents in relation to insect spoilage.

The dehydration of foods is dealt with in masterly fashion but to anybody who has investigated or even eaten these products, it is no surprise to learn that the conditions of storage are vital to palatability. The authors also fight shy of the nutritional aspects of these foods, while no mention is made of compression as a method of saving space and packaging.

Food preservation by temperature control is written by Dr. Tressler, a noted authority on this subject. He has, however, too much ground to cover in twenty pages, and as a result he inevitably sounds dogmatic even on difficult and complicated points such as the meaning of and the desirable relative humidity for the storage of a particular foodstuff at a given temperature.

The sections on production are all first-class, as would be expected from the names at the head of them. When they are objective, however, they refer inevitably to American practice. Thus Dr. Urbain gives a lucid account of operations in the Chicago stockyards, Prof. Geddes makes no mention of wheat blending which is of such interest to many European countries, and also scarcely mentions rye, while discussing maize in some detail. On the other hand, there is a stimulating section on alcoholic beverages, which includes a short chapter on Scotch whisky.

This volume, like its predecessor, is largely an account of American laboratory and commercial experience on the properties and production of foods. It is, however, a welcome addition to the literature on food technology, and Dr. Jacobs is to be con. gratulated both on his courage and his achievement.

T. Moran. 